\title{
Night eating syndrome: How to treat it?
}

\author{
Thisciane Ferreira Pinto ${ }^{1}$, Francisco Girleudo Coutinho da Silva ${ }^{2}$, Veralice Meireles Sales de Bruin ${ }^{3}$, \\ Pedro Felipe Carvalhedo de Bruin ${ }^{4 *}$ \\ ${ }^{1} \mathrm{MSc}$ in Pharmaceutical Sciences. Universidade Federal do Ceará (UFC), Fortaleza, CE, Brazil \\ "MSc in Medical Sciences. UFC, Fortaleza, CE, Brazil \\ ${ }^{3} \mathrm{PhD}$ in Psychobiology. Associate Professor, Department of Clinical Medicine, UFC, Fortaleza, CE, Brazil \\ ${ }^{4} \mathrm{PhD}$ in Medicine (Pneumology). Associate Professor, Department of Clinical Medicine, UFC, Fortaleza, CE, Brazil
}

Study conducted at Departamento de Medicina Clínica, Faculdade de Medicina, Universidade Federal do Ceará (FMUFC), Fortaleza, CE, Brazil

Article received: $7 / 21 / 2015$ Accepted for publication: 9/28/2015

*Correspondence:

Departamento de Medicina Clínica Address: Rua Prof. Costa Mendes, 1608 , $4^{\circ}$ andar Fortaleza, CE - Brazil Postal code: 60430-140 pedrobruin@gmail.com

\section{SUMMARY}

Night eating syndrome (NES) is characterized by caloric intake $\geq 25 \%$ of total daily after dinner and/or by two or more weekly nocturnal awakenings accompanied by food ingestion. Causes of NES are not entirely clear and seem to involve a desynchronization between the circadian rhythms of food ingestion and sleep, resulting in a delayed pattern of food intake. Estimates of the prevalence of NES in the general population are around $1.5 \%$, and although much higher frequencies have been described in obese individuals, a causal relationship between NES and obesity is not clearly established. Since the first NES reports, several treatment modalities have been proposed, although, in many cases, the evidence is still insufficient and there is no consensus on the ideal approach. In order to conduct a critical review of proposed treatments for NES since its original description, a systematic search of articles published in journals indexed in Medline/ Pubmed database in the period 1955-2015 was performed. Seventeen articles addressing non-pharmacological and pharmacological therapies met the selection criteria. Based on the articles analyzed, we conclude that serotonergic agents and psychological interventions, particularly cognitive behavioral therapy, have been shown to be effective for the treatment of NES. A combination of non-pharmacological and pharmacological therapies must be considered in future studies on the treatment of these patients.

Keywords: circadian rhythm, obesity, eating disorders, sleep disorders.

\section{INTRODUCTION}

Night eating syndrome (NES) was originally described by Stunkard et al., in 1955, in obese patients treated at a specialized clinic for nocturnal hyperphagia, insomnia, and morning anorexia. ${ }^{1}$ Its main feature is a delay in the pattern of food intake, usually defined by ingestion of at least $25 \%$ of total daily calories after dinner and/or during nocturnal awakenings. In the Diagnostic and Statistical Manual of Mental Disorders, Fifth Edition (DSM-5), NES is classified in the category of eating disorders not otherwise specified. ${ }^{2,3}$

The prevalence of NES in the general population is approximately $1.5 \%$. In contrast, this syndrome is present in 6 to $14 \%$ of patients in clinical follow-up for weight loss and 8.9 to $42 \%$ of candidates for bariatric surgery. ${ }^{4-6}$ High frequencies, close to $12 \%$, have also been reported in psychiatric patients. ${ }^{7}$ A prevalence of $3.8 \%$ was observed for NES in elderly patients with type 2 diabetes, ${ }^{8} 8.6 \%$ in patients with sleep apnea, ${ }^{9}$ and $17 \%$ in patients with restless legs syndrome. ${ }^{10}$

The causes of NES are not fully understood but appear to involve a desynchronization between the rhythms of food intake and sleep. Despite the delay in the circadian pattern of food intake typically observed in these patients, changes in sleep-wake rhythm (the beginning and end of the sleep time) have not been demonstrated in actigraphic and polysomnographic studies. ${ }^{11,12}$ In normal individuals, energy homeostasis is controlled by a neurohumoral system that minimizes the impact of small fluctuations in energy balance, and leptin and insulin are critical elements in this control. The nighttime sleep period is characterized by prolonged fasting, where the en- 
ergy balance is maintained through hormonal changes. ${ }^{13}$ In patients with NES, leptin levels tend to be reduced at night, which may contribute to nocturnal awakenings accompanied by food ingestion. A reduction in the levels of ghrelin, probably due to the nocturnal food intake itself, has also been described in these individuals. Low levels of melatonin have been implicated in the desynchronization process found in NES. ${ }^{14-16}$

The relationship between NES and obesity is not fully understood. Studies in overweight and obese patients, usually recruited from specialized clinics, have shown a high frequency of NES compared to community controls, suggesting the existence of a relationship between NES and obesity. ${ }^{5,17-20}$ However, epidemiological studies have not confirmed whether this association exists ${ }^{5,21}$ and numerous cross-sectional studies show inconsistent results. ${ }^{17,22-24}$ These contradictory results can be attributed, at least in part, to methodological issues such as differences in the operational definition of NES, small variation in body mass index (BMI) in homogeneous populations or insufficient statistical power to identify differences between groups. In an attempt to overcome the limitations of previous studies, Colles et al. (2007) recruited 431 individuals with BMI ranging from less than 18 to over 65 $\mathrm{kg} / \mathrm{m}^{2}$ and identified an independent association between NES and BMI. ${ }^{20}$ Although a relationship between obesity and NES is considered probable, its exact nature remains uncertain. Adult obese patients with NES are, on average, older than obese individuals without NES, which suggests that NES leads to weight gain over time. ${ }^{25}$ Recently, a study including 2,317 individuals showed a positive correlation between the intensity of night eating symptoms and BMI in the age group from 30 to 60 years, but not in younger individuals, suggesting that age plays an important role in the relationship between NES and obesity and the weight gain occurs only after long periods of nocturnal feeding habits. ${ }^{26} \mathrm{~A}$ prospective study lasting 6 years found that women who get up at night to eat significantly gain more weight. ${ }^{27} \mathrm{~A}$ longitudinal study of the variation of body weight showed that individuals who eat between $11 \mathrm{pm}$ and 5 am hours gain more weight than those who do not eat during this period. ${ }^{28}$ Although the evidence, as a whole, points to a causal relationship between NES and obesity, difficulty in controlling for several variables and external factors of environmental, socioeconomic, genetic, and behavioral nature prevents a definitive conclusion. It is reasonable to assume that in subjects with night eating habits, high intake at night hours, not offset by a similar increase in energy expenditure, leads to a positive balance and, over time, weight gain. It is also possible that NES involves a general tendency to excessive food consumption. Controlled studies to investigate the excessive food intake in patients with NES produced conflicting results. ${ }^{11,15,29}$ Conversely, the reverse hypothesis that weight gain and obesity may influence the characteristics of NES must be considered. In this regard, individuals with limited food intake in the morning could have a more deregulated intake overnight. Furthermore, the guilt associated with weight gain could lead to a greater tendency to overeat in the privacy of one's home. ${ }^{30}$

The diagnosis of NES is eminently clinical. The current criteria established in the International Symposium of 2008 include evening hyperphagia, defined by consumption greater than or equal to $25 \%$ of total daily calories after dinner and/or nocturnal awakenings accompanied by food intake plus at least three of the following five: i) morning anorexia, ii) insomnia, iii) desire to eat between dinner and bedtime, iv) need to eat to fall asleep or return to sleep, and v) depressed mood, most often at night. ${ }^{2}$ In order to screen patients and to help evaluate the response to treatment, some useful tools have been developed, including the Night Eating Questionnaire. ${ }^{31,32}$ The main conditions to be considered as a differential diagnosis include other eating disorders, particularly the binge eating disorder, characterized by eating large amounts of food in a short time, with feeling of loss of control, depressed mood, and lack of compensatory behaviors. ${ }^{4,14,33}$

Eating disorders in general tend to be associated with a spectrum of clinical manifestations and behavioral changes for which a multidisciplinary approach is often considered more effective. ${ }^{34}$ In the case of NES, although several options have been investigated, there is no consensus on the optimal treatment. ${ }^{29,35-39}$ The aim of this study was to critically evaluate the therapeutic alternatives proposed so far for the management of this condition.

\section{Method}

We conducted a systematic search of articles published in journals indexed in the PubMed (US National Library of Medicine - National Institutes of Health) database since 1955, the year that NES was originally described, until June 2015. The keywords used in the search were: "night eating syndrome" and "nocturnal eating", with no language restrictions. The reference lists of selected articles were reviewed to expand the initial search.

\section{Results}

486 articles were retrieved (258 having as keywords "night eating syndrome"). After reading the summaries, 469 were 
excluded because they did not address our subject of study. The 17 selected articles included case reports, case series, and clinical trials, involving non-pharmacological and pharmacological treatment modalities.

\section{Non-pharmacological treatment}

Administration of bright light in the morning has produced beneficial effects in patients with seasonal affective disorder, a condition in which changes in sleep and mood patterns, as well as in circadian neurobiological markers similar to those seen in NES, are observed. ${ }^{40,41}$ This led some groups to assess its applicability in the management of patients with NES. Friedman et al. (2002) reported that a patient with NES treated with $40 \mathrm{mg} /$ day of paroxetine for depressive symptoms, who underwent 14 morning sessions of phototherapy with 10,000 lux white light for 30 minutes, showed improvement of depression and symptoms of night eating. After one month, there was a recurrence of eating-related symptoms, although the intensity of depressive symptoms remained low. The authors decided to start the morning phototherapy, obtaining complete suppression of eating-related symptoms after 12 sessions. ${ }^{42}$ Subsequently, the same group reported the case of a non-obese patient with NES and depression, who underwent morning phototherapy with 10,000 lux of white light for 30 minutes; after 14 sessions, improvement of depression and symptoms of NES was observed. ${ }^{43}$

The effect of progressive muscle relaxation therapy on stress, mood, hunger, and eating pattern was evaluated by Pawlow et al. (2003) in 20 individuals with NES randomly assigned to a treatment or control group. In the latter, patients remained at rest for the same time duration of the therapy session. There were two sessions lasting 20 minutes each, carried out one week apart. The levels of stress, relaxation, and salivary cortisol were determined before and after each session. In addition, in the first and eighth day, the authors evaluated the mood. It was observed that progressive muscle relaxation reduces the levels of stress, anxiety and salivary cortisol immediately after the session. This technique was associated with increased morning hunger and reduced night eating. ${ }^{44}$

Cognitive behavioral therapy (CBT) has been successfully used in the management of various conditions, including depression, insomnia, and some eating disorders. Allison (2012) proposed a brief but intensive model of CBT for NES that includes information on NES, guidance on sleep hygiene and healthy nutrition, self-monitoring of eating habits, exercise, and relaxation strategies. ${ }^{45} \mathrm{~A}$ non-controlled pilot study with 25 participants (19 female) on the use of CBT in cases of NES showed an improvement in symptoms and weight loss. ${ }^{46}$

Vander Wal et al. (2015) conducted a clinical trial involving patients with symptoms of NES randomized to receive only educational measures, educational measures, and relaxation with exercise, or educational measures and relaxation without exercise. The three groups showed a reduction in symptoms of NES, depression, anxiety, and perceived stress. The reduction in the percentage of food eaten after the last meal was higher in the group with educational measures and relaxation without exercise. These results suggest that educational measures associated with relaxation techniques have a promising role in the management of patients with this condition. ${ }^{47}$ Studies on non-pharmacological treatment of NES are summarized in Table 1.

\section{Pharmacological treatment}

It is believed that neuroendocrine alterations associated with changes in the rhythm of food intake are important in the pathogenesis of NES. It has been suggested that in these patients there would be a relative deficiency of postsynaptic serotonin in the mesencephalic nuclei, caused by hyperactivity of the carrier system, which would lead to a defect in the regulation by the central nervous system of sleeping and feeding rhythms. Thus, the use of selective serotonin reuptake inhibitors (SSRIs), which reduces the binding of serotonin transporters and increases postsynaptic serotonin, could restore circadian function and satiety. ${ }^{15,39}$ Favorable results of the use of SSRIs to treat obesity ${ }^{48,49}$ and other eating disorders such as anorexia nervosa and binge eating disorder have been reported. ${ }^{50-52}$ Miyaoka et al. (2003) prescribed paroxetine $(n=3)$ or fluvoxamine $(n=1)$, SSRIs, to four patients with NES characteristics and reported effective control of nocturnal eating episodes after 2 to 3 weeks of treatment. ${ }^{37}$ In an open clinical trial with 17 participants with NES characteristics, O'Reardon et al. (2004) evaluated the effect of other SSRI, sertraline, for 12 weeks on the number of awakenings, nocturnal food intake, and ingestion of food after dinner, and observed an improvement of all the aspects evaluated in all patients. Five patients had significant weight loss, close to $5 \mathrm{~kg}$ on average. ${ }^{38}$ O'Reardon et al. (2006) conducted a randomized double-blind placebo-controlled study to assess the efficacy of sertraline for 8 weeks in 28 patients with NES. The authors reported a significant reduction in the number of awakenings with nighttime eating. In addition, an average weight reduction of about $3 \mathrm{~kg}$ was observed in the sertraline group but not in the placebo group. ${ }^{53}$ 
TABLE 1 Summary of studies involving non-pharmacological treatment of patients with night eating syndrome.

\begin{tabular}{|c|c|c|c|c|c|}
\hline Author & Study type & Treatment & Sample characteristics & Duration & Result \\
\hline Friedman, & Case report & Phototherapy 10,000 & 1 female aged 51 years with & 14 days & Improvement of depressive \\
\hline $2002^{42}$ & & lux for 30 minutes & NES, obese & & symptoms and nocturnal eating \\
\hline \multirow[t]{2}{*}{ Pawlow, $2003^{44}$} & Controlled & \multirow[t]{2}{*}{ PMR } & 20 participants with NES & \multirow[t]{2}{*}{1 week } & Reduction of nocturnal appetite \\
\hline & clinical trial & & (intervention, $\mathrm{n}=10 ;$ control, $\mathrm{n}=10$ ) & & and increased morning hunger \\
\hline Friedman, & Case report & Phototherapy 10,000 & 1 male aged 46 years with NES, & 14 days & Improvement of depressive \\
\hline $2004^{43}$ & & lux for 30 minutes & not obese & & symptoms and NES \\
\hline \multirow[t]{2}{*}{ Allison, $2010^{46}$} & Non-controlled & \multirow[t]{2}{*}{ CBT } & 25 participants with NES & \multirow[t]{2}{*}{12 weeks } & Improvement of depressive \\
\hline & clinical trial & & (19 women) & & symptoms and NES; weight loss \\
\hline \multirow{3}{*}{$\begin{array}{l}\text { Vander Wal, } \\
2015^{47}\end{array}$} & \multirow{3}{*}{$\begin{array}{l}\text { Controlled } \\
\text { clinical trial }\end{array}$} & \multirow{3}{*}{$\begin{array}{l}\text { CBT, exercise, and } \\
\text { education }\end{array}$} & 44 patients with NES (education, & \multirow{3}{*}{3 weeks } & Improvement of NES using any \\
\hline & & & $\mathrm{n}=14 ;$ CBT without exercise, $\mathrm{n}=15$; & & of the three interventions \\
\hline & & & CBT with exercise, $n=14$ ) & & \\
\hline
\end{tabular}

NES: night eating syndrome; PMR: progressive muscle relaxation; CBT: cognitive behavioral therapy.

Stunkard et al. (2006) conducted an open clinical trial, at distance, to evaluate the effectiveness of sertraline in the treatment of NES. Patients who spontaneously sought the help of researchers via website, email or phone were asked to fill the Night Eating Questionnaire and underwent a structured interview to determine the presence of NES. Fifty participants were treated with sertraline, which was prescribed by their own doctors. To evaluate the response, the questionnaire was completed every 2 weeks and the interview repeated at the end of 8 weeks. The researchers reported improvement in nocturnal hyperphagia, nocturnal awakenings with food intake, and depressive symptoms. ${ }^{54}$ Vander Wal et al. (2012) conducted a randomized placebo-controlled trial of 40 patients with NES to evaluate the effect of escitalopram, an other SSRI, for 12 weeks, and found no difference between groups in the reduction of the symptoms of NES assessed based on the Night Eating Questionnaire, weight loss, mood, and adverse events. ${ }^{55}$ In contrast, Allison et al. (2013), in a clinical trial involving 31 patients with NES to evaluate the use of escitalopram, found a significant reduction in nocturnal hyperphagia and nocturnal awakenings accompanied by food intake, measured based on the Night Eating Symptom Scale, after 12 weeks. $^{56}$

The use of topiramate, an agonist of gamma aminobutyric acid, in patients with NES has been reported by some authors. Winkelman (2003) observed a reduction in nocturnal awakenings with food intake, improved sleep and weight loss in two patients who failed prior treatments with psychotherapy and pharmacotherapy. ${ }^{35}$ Tucker et al. (2004) reported the case of a 40-year-old obese woman treated with topiramate for 8 months, who achieved reduction in episodes of nocturnal awakenings accompanied by food intake. ${ }^{36}$ Cooper-Kazaz (2012) reported the case of a non-obese female patient under treatment for depression with venlafaxine, who developed NES and weight gain. She received topiramate for 6 weeks, with improvement of night eating symptoms, sleep quality, self-esteem and well-being, and weight loss. ${ }^{57}$

A decrease in nocturnal melatonin levels in patients with NES has been reported. ${ }^{15}$ Based on this finding, agomelatine, an agonist of the MT1 and MT2 receptors, has been considered as an option for treatment of NES. ${ }^{58,59}$ Milano et al. (2013) gave agomelatine $(25 \mathrm{mg} /$ day during the first 3 weeks and $50 \mathrm{mg} /$ day in the subsequent weeks) for 12 weeks to five patients with symptoms of NES and depression, and observed improvement in clinical symptoms, mood, and number of nocturnal awakenings, as well as weight reduction. ${ }^{60}$ Given the strong association between NES and changes in the sleep-wake and eating cycles, in addition to the frequent finding of depressive symptoms and low melatonin levels, new studies are required in order to properly assess the efficacy of agomelatine to treat this syndrome. Studies on the pharmacological treatment of NES are summarized in Table 2.

\section{Conclusion}

This critical review of the literature on the treatment of NES in the last 60 years shows that the number of studies is still insufficient, especially regarding controlled clinical trials with adequate sample size and methodology. The results above suggest that serotonergic agents and psychological interventions such as the CBT can be effective in the treatment of NES. Among the SSRIs, sertraline was the drug most studied for this condition. Preliminary reports of beneficial effects of topiramate and agomelatine justify further studies involving these substances and 
TABLE 2 Summary of studies involving pharmacological treatment of patients with night eating syndrome.

\begin{tabular}{|c|c|c|c|c|c|}
\hline Author & Study type & Treatment & $\begin{array}{l}\text { Sample } \\
\text { characteristics }\end{array}$ & Duration & Result \\
\hline $\begin{array}{l}\text { Miyaoka, } \\
2003^{37}\end{array}$ & Case series & $\begin{array}{l}\text { Paroxetine ( } 3 \text { cases); } \\
\text { fluvoxamine ( } 1 \text { case) }\end{array}$ & 4 patients with NES & 2 weeks & $\begin{array}{l}\text { Effective control of episodes of } \\
\text { nocturnal eating after 2-3 weeks } \\
\text { of treatment }\end{array}$ \\
\hline $\begin{array}{l}\text { Winkelman, } \\
2003^{35}\end{array}$ & Case series & Topiramate & 2 patients with NES & $\mathrm{N} / \mathrm{I}$ & $\begin{array}{l}\text { Improved night eating, weight loss; } \\
\text { the symptoms of NES returned one } \\
\text { month after the end of treatment }\end{array}$ \\
\hline $\begin{array}{l}\text { Tucker, } \\
2004^{36}\end{array}$ & Case report & Topiramate & 1 female aged 40 years & 9 months & $\begin{array}{l}\text { Improvement of symptoms of NES, } \\
\text { sleepiness; weight loss }\end{array}$ \\
\hline $\begin{array}{l}\text { O'Reardon, } \\
2004^{38}\end{array}$ & Open clinical trial & Sertraline & $\begin{array}{l}17 \text { participants with NES } \\
\text { (12 women) }\end{array}$ & 12 weeks & $\begin{array}{l}\text { Reduction in the number of awakenings; } \\
\text { improvement in night eating }\end{array}$ \\
\hline $\begin{array}{l}\text { O'Reardon, } \\
2006^{48}\end{array}$ & $\begin{array}{l}\text { Double-blind, } \\
\text { randomized, } \\
\text { placebo-controlled trial }\end{array}$ & Sertraline & $\begin{array}{l}34 \text { participants with } \\
\text { NES (sertraline, } n=17 \text {; } \\
\text { placebo, } n=17 \text { ) }\end{array}$ & 8 weeks & $\begin{array}{l}\text { Improvement in symptoms of NES } \\
\text { and in quality of life; weight loss }\end{array}$ \\
\hline $\begin{array}{l}\text { Stunkard, } \\
2006^{49}\end{array}$ & Open clinical trial & Sertraline & $\begin{array}{l}50 \text { participants with } \\
\text { NES }\end{array}$ & $\begin{array}{l}\text { Not } \\
\text { informed }\end{array}$ & $\begin{array}{l}\text { Improvement in nocturnal hyperphagia, } \\
\text { nocturnal awakenings with food intake, } \\
\text { and depressive symptoms }\end{array}$ \\
\hline $\begin{array}{l}\text { Cooper-Kazaz, } \\
2012^{52}\end{array}$ & Case report & Topiramate & $\begin{array}{l}1 \text { female aged } 54 \text { years } \\
\text { with NES and depression }\end{array}$ & 3 months & $\begin{array}{l}\text { Improvement in symptoms of NES, } \\
\text { sleep quality and self-esteem }\end{array}$ \\
\hline $\begin{array}{l}\text { Vander Wal, } \\
2012^{50}\end{array}$ & $\begin{array}{l}\text { Controlled randomized } \\
\text { clinical trial }\end{array}$ & Escitalopram & $\begin{array}{l}40 \text { participants with NES } \\
\text { (escitalopram, } n=20 \text {; } \\
\text { placebo, } n=20 \text { ) }\end{array}$ & 6 weeks & $\begin{array}{l}\text { Improvement in symptoms of NES } \\
\text { and weight loss did not differ between } \\
\text { the groups }\end{array}$ \\
\hline $\begin{array}{l}\text { Allison, } \\
2013^{51}\end{array}$ & Open clinical trial & Escitalopram & $\begin{array}{l}31 \text { patients with NES } \\
\text { ( } 21 \text { women) }\end{array}$ & 12 weeks & $\begin{array}{l}\text { Improvement in NES and } \\
\text { depressive symptoms }\end{array}$ \\
\hline $\begin{array}{l}\text { Milano, } \\
2013^{55}\end{array}$ & Case series & Agomelatine & $\begin{array}{l}5 \text { patients with NES } \\
\text { ( } 3 \text { women })\end{array}$ & 10 weeks & $\begin{array}{l}\text { Improvement in symptoms of NES } \\
\text { and depression; weight loss }\end{array}$ \\
\hline $\begin{array}{l}\text { Milano, } \\
2013^{54}\end{array}$ & Case report & Agomelatine & $\begin{array}{l}1 \text { female aged } 39 \text { years } \\
\text { with NES and depression }\end{array}$ & 3 months & $\begin{array}{l}\text { Improvement in mood and symptoms } \\
\text { of NES; weight loss }\end{array}$ \\
\hline
\end{tabular}

NES: night eating syndrome; N/I: not informed.

similar medications. Similarly, an initial report of benefits obtained with phototherapy suggests that chronobiological treatments can be useful and should be further examined. Finally, in view of the complexity of the manifestations of NES and its frequent association with obesity, mood disorders, and other comorbidities, the combination of non-pharmacological and pharmacological therapies coupled with a multidisciplinary approach needs to be considered in future studies on the treatment of these patients.

\section{ACKNOWLeDGMents}

Thisciane Ferreira Pinto was awarded a PhD grant from Coordenação de Aperfeiçoamento de Pessoal de Nível Superior (CAPES), Brazil. Francisco Girleudo Coutinho da Silva was awarded an MSc grant from Fundação Cearense de Amparo à Pesquisa (FUNCAP). Veralice Meireles
Sales de Bruin was awarded a researcher grant from the Conselho Nacional de Pesquisa e Desenvolvimento Tecnológico (CNPq).

\section{Resumo}

Síndrome do comer noturno: como tratar?

A síndrome do comer noturno (SCN) caracteriza-se por ingestão calórica $\geq 25 \%$ do total diário após o jantar e/ou por dois ou mais despertares noturnos semanais acompanhados de alimentação. As causas da SCN não estão totalmente esclarecidas e parecem envolver uma dessincronização entre os ritmos circadianos de alimentação e sono, resultando em um atraso do padrão alimentar. Estimativas da prevalência de SCN na população geral estão em torno de $1,5 \%$ e, embora frequências bem mais elevadas 
tenham sido descritas em obesos, uma relação de causalidade entre SCN e obesidade não está claramente estabelecida. Desde os primeiros relatos da SCN, várias modalidades de tratamento têm sido propostas, embora, em muitos casos, a evidência ainda seja insuficiente e não exista um consenso sobre a abordagem ideal. Com o objetivo de realizar uma revisão crítica dos tratamentos propostos para a $\mathrm{SCN}$, desde sua descrição original, foi realizada uma busca sistemática de artigos publicados nos periódicos indexados na base de dados MedLine / Pubmed entre 1955 e 2015. Dezessete artigos, abordando terapias não farmacológicas ou farmacológicas, preencheram os critérios de seleção. Com base nos artigos analisados, conclui-se que os agentes serotonérgicos e intervenções psicológicas, particularmente, a terapia cognitivo-comportamental, têm mostrado eficácia no tratamento da SCN. Uma combinação de terapias não farmacológicas e farmacológicas precisa ser considerada em estudos futuros sobre o tratamento desses pacientes.

Palavras-chave: ritmo circadiano, obesidade, transtornos alimentares, transtornos do sono.

\section{RefEREnCES}

1. Stunkard AJ, Grace WJ, Wolff HG. The night-eating syndrome: a pattern of food intake among certain obese patients. Am J Med. 1955; 19(1):78-86.

2. Association AP. The Diagnostic and Statistical Manual of Mental Disorders: DSM 5: bookpointUS; 2013.

3. Cleator J, Abbott J, Judd P, Sutton C, Wilding J. Night eating syndrome: implications for severe obesity. Nutr Ddiabetes 2012; 2:e44.

4. Allison KC, Grilo CM, Masheb RM, Stunkard AJ. Binge eating disorder and night eating syndrome: a comparative study of disordered eating. J Consult Clin Psychol. 2005; 73(6):1107-15.

5. Rand CSW, Macgregor A, Stunkard AJ. The night eating syndrome in the general population and among postoperative obesity surgery patients. Int J Eat Disord. 1997; 22(1):65-9.

6. Hsu LK, Sullivan SP, Benotti PN. Eating disturbances and outcome of gastric bypass surgery: a pilot study. Int J Eat Disord. 1997; 21(4):385-90.

7. Lundgren JD, Allison KC, Crow S, O'Reardon JP, Berg KC, Galbraith J, et al. Prevalence of the night eating syndrome in a psychiatric population. Am J Psychiatry. 2006; 163(1):156-8.

8. Allison KC, Crow SJ, Reeves RR, West DS, Foreyt JP, Dilillo VG, et al.; the Eating Disorders Subgroup of the Look AHEAD Research Group. Binge eating disorder and night eating syndrome in adults with type 2 diabetes. Obesity (Silver Spring). 2007; 15(5):1287-93.

9. Olbrich K, Mühlhans B, Allison KC, Hahn EG, Schahin SP, de Zwaan M. Night eating, binge eating and related features in patients with obstructive sleep apnea syndrome. Eur Eating Disord Rev. 2009; 17(2):120-7.

10. Antelmi E, Vinai P, Pizza F, Marcatelli M, Speciale M, Provini F. Nocturnal eating is part of the clinical spectrum of restless legs syndrome and an underestimated risk factor for increased body mass index. Sleep Med. 2014; 15(2):168-72.

11. O'Reardon JP, Ringel BL, Dinges DF, Allison KC, Rogers NL, Martino NS, et al. Circadian eating and sleeping patterns in the night eating syndrome. Obesity Res. 2004; 12(11):1789-96.

12. Rogers N, Dinges D, Allison K. Maislin G, Martino N, O'Reardon JP, et al. Assessment of sleep in women with night eating syndrome. Sleep. 2006; 29(6):814-9.

13. Gibbert GA, Brito MN. Relações fisiológicas entre o sono e a liberação de hormônios que regulam o apetite. Rev Saúde e Pesquisa. 2011; 4(2):271-7.
14. Bernardi F, Harb ABC, Levandovski RM, Hidalgo MPL. Eating disorders and circadian eating pattern: a review. Rev Psiquiatr Rio Gd Sul. 2009; 31(3):170-6.

15. Birketvedt GS, Florholmen J, Sundsfjord J, Osterud B, Dinges D, Bilker W, et al. Behavioral and neuroendocrine characteristics of the night-eating syndrome. JAMA. 1999; 282(7):657-63.

16. Crispim CA, Zalcman I, Dáttilo M, Padilha HG, Tufik S, Mello MT. Relation between sleep and obesity: a literature review. Arq Bras Endocrinol Metab. 2007; 51(7):1041-9.

17. Adami GF, Campostano A, Marinari GM, Ravera G, Scopinaro N. Night eating in obesity: a descriptive study. Nutrition. 2002; 18(7-8):587-9.

18. Latner JD, Wetzler S, Goodman ER, Glinski J. Gastric bypass in a low-income, inner-city population: eating disturbances and weight loss. Obes Res. 2004; 12(6):956-61.

19. Striegel-Moore RH, Franko DL, Thompson D, Affenito S, May A, Kraemer HC. Exploring the typology of night eating syndrome. Int J Eating Disord. 2008; 41(5):411-8.

20. Colles S, Dixon J, O'Brien P. Night eating syndrome and nocturnal snacking: association with obesity, binge eating and psychological distress. Int J Obes (Lond). 2007; 31(11):1722-30.

21. Striegel-Moore RH, Franko DL, Thompson D, Affenito S, Kraemer HC. Night eating: prevalence and demographic correlates. Obesity (Silver Spring). 2006; 14(1):139-47.

22. Gluck ME, Geliebter A, Satov T. Night eating syndrome is associated with depression, low self-esteem, reduced daytime hunger, and less weight loss in obese outpatients. Obes Res. 2001; 9(4):264-7.

23. Napolitano MA, Head S, Babyak MA, Blumenthal JA. Binge eating disorder and night eating syndrome: psychological and behavioral characteristics. Int J Eating Disord. 2001; 30(2):193-203.

24. Cerú-Björk C, Andersson I, Rössner S. Night eating and nocturnal eatingtwo different or similar syndromes among obese patients? Int J Obes Relat Metab Disord. 2001; 25(3):365-72.

25. Marshall HM, Allison KC, O'Reardon JP, Birketvedt G, Stunkard AJ. Night eating syndrome among nonobese persons. Int J Eating Disord. 2004; $35(2): 217-22$.

26. Meule A, Allison KC, Platte P. A German version of the Night Eating Questionnaire (NEQ): Psychometric properties and correlates in a student sample. Eat Behav. 2014; 15(4):523-7.

27. Andersen GS, Stunkard AJ, Sørensen TI, Petersen L, Heitmann BL. Night eating and weight change in middle-aged men and women. Int J Obes Relat Metab Disord. 2004; 28(10):1338-43.

28. Gluck ME, Venti CA, Salbe AD, Krakoff J. Nighttime eating: commonly observed and related to weight gain in an inpatient food intake study. Am J Clin Nutr. 2008; 88(4):900-5.

29. Allison KC, Ahima RS, O'Reardon JP, Dinges DF, Sharma V, Cummings DE, et al. Neuroendocrine profiles associated with energy intake, sleep, and stress in the night eating syndrome. J Clin Endocrinol Metab. 2005; 90(11):6214-7.

30. Colles SL, Dixon JB. Night eating syndrome: impact on bariatric surgery. Obes Surg. 2006; 16(7):811-20.

31. Dantas GM, Pinto TF, Pereira EDB, Junior RMM, Bruin VMS, Bruin PFC. Validation of a new Brazilian version of the "Night Eating Questionnaire". Sleep Science, 2012; 5(1):7-13.

32. Allison KC, Lundgren JD, O'Reardon JP, Martino NS, Sarwer DB, Wadden TA, et al. The Night Eating Questionnaire (NEQ): Psychometric properties of a measure of severity of the night eating syndrome. Eat Behav. 2008; 9(1):62-72.

33. Ferriter C, Ray LA. Binge eating and binge drinking: an integrative review. Eat Behav. 2011; 12(2):99-107.

34. Claudino AdM, Zanella MT. Guia de transtornos alimentares e obesidade. Barueri: Manole; 2005

35. Winkelman JW. Treatment of nocturnal eating syndrome and sleep-related eating disorder with topiramate. Sleep Med. 2003; 4(3):243-6.

36. Tucker P, Masters B, Nawar O. Topiramate in the treatment of comorbid night eating syndrome and PTSD: a case study. Eat Disord. 2004; 12(1):75-8.

37. Miyaoka T, Yasukawa R, Tsubouchi K, Miura S, Shimizu Y, Sukegawa T, et al. Successful treatment of nocturnal eating/drinking syndrome with selective serotonin reuptake inhibitors. Int Clin Psychopharmacol. 2003; 18(3):175-7.

38. O'Reardon JP, Stunkard AJ, Allison KC. Clinical trial of sertraline in the treatment of night eating syndrome. Int J Eat Disord. 2004; 35(1):16-26.

39. Stunkard AJ, Allison K, Lundgren J, O'Reardon J. A biobehavioural model of the night eating syndrome. Obes Rev. 2009; 10(Suppl 2):69-77. 
40. Goel N, Stunkard AJ, Rogers NL, Van Dongen HP, Allison KC, O’Reardon $\mathrm{JP}$, et al. Circadian rhythm profiles in women with night eating syndrome. J Biol Rhythms. 2009; 24(1):85-94.

41. Pawlow L. Other approaches to the treatment of night eating syndrome. In: Lundgren J, Allison K, Stunkard A, editors. Night eating syndrome: research, assessment, and treatment. New York: Guilford Press; 2012. p. 266-81.

42. Friedman S, Even C, Dardennes R, Guelfi JD. Light therapy, obesity, and night-eating syndrome. Am J Psychiatry. 2002; 159(5):875-6.

43. Friedman S, Even C, Dardennes R, Guelfi JD. Light therapy, nonseasonal depression, and night eating syndrome. Can J Psychiatry. 2004; 49(11):790.

44. Pawlow L, O'Neil P, Malcolm R. Night eating syndrome: effects of brief relaxation training on stress, mood, hunger, and eating patterns. Int $\mathrm{J}$ Obes Relat Metab Disord. 2003; 27(8):970-8.

45. Allison K. Cognitive-behavioral therapy manual for night eating syndrome. In: Lundgren J, Allison K, Stunkard A, editors. Night eating syndrome: research, assessment, and treatment New York: Guilford Press; 2012. p. 246-65.

46. Allison KC, Lundgren JD, Moore RH, O'Reardon JP, Stunkard AJ. Cognitive behavior therapy for night eating syndrome: a pilot study. Am J Psychother. 2010; 64(1):91-106.

47. Vander Wal JS, Maraldo TM, Vercellone AC, Gagne DA. Education, progressive muscle relaxation therapy, and exercise for the treatment of night eating syndrome. A pilot study. Appetite. 2015; 89:136-44.

48. Halford JC, Boyland EJ, Lawton CL, Blundell JE, Harrold JA. Serotonergic anti-obesity agents: past experience and future prospects. Drugs. 2011; 71(17):2247-55

49. Crane JD, Palanivel R, Mottillo EP, Bujak AL, Wang H, Ford RJ, et al. Inhibiting peripheral serotonin synthesis reduces obesity and metabolic dysfunction by promoting brown adipose tissue thermogenesis. Nat Med. $2015 ; 21(2): 166-72$.
50. Sebaaly JC, Cox S, Hughes CM, Kennedy MLH, Garris SS. Use of fluoxetine in anorexia nervosa before and after weight restoration. Ann Pharmacother 2013; 47(9):1201-5.

51. Flament MF, Bissada H, Spettigue W. Evidence-based pharmacotherapy of eating disorders. Int J Neuropsychopharmacol. 2012; 15(2):189-207.

52. Crow S. Treatment of binge eating disorder. Curr Treat Options Psychiatry. 2014; 1(4):307-14.

53. O'Reardon J, Allison K, Martino N, Lundgren J, Heo M, Stunkard A. A randomized, placebo-controlled trial of sertraline in the treatment of night eating syndrome. Am J Psychiatry. 2006; 163(5):893-8.

54. Stunkard AJ, Allison KC, Lundgren JD, Martino NS, Heo M, Etemad B, et al. A paradigm for facilitating pharmacotherapy at a distance: sertraline treatment of the night eating syndrome. J Clin Psychiatry. 2006; 67(10):1568-72.

55. Vander Wal JS, Gang CH, Griffing GT, Gadde KM. Escitalopram for treatment of night eating syndrome: a 12 -week, randomized, placebo-controlled trial. J Clin Psychopharmacol. 2012; 32(3):341-5.

56. Allison KC, Studt SK, Berkowitz RI, Hesson LA, Moore RH, Dubroff JG, et al. An open-label efficacy trial of escitalopram for night eating syndrome. Eat Behav. 2013; 14(2):199-203.

57. Cooper-Kazaz R. Treatment of night eating syndrome with topiramate: dawn of a new day. J Clin Psychopharmacol. 2012; 32(1):143-5.

58. Milano W, De Rosa M, Milano L, Capasso A. Night eating syndrome: an overview. J Pharm Pharmacol. 2012; 64(1):2-10.

59. Milano W, De Rosa M, Milano L, Capasso A. Agomelatine efficacy in the night eating syndrome. Case Rep Med. 2013; 2013(2013):867650.

60. Milano W, De Rosa M, Milano L, Riccio A, Sanseverino B, Capasso A Successful treatment with agomelatine in NES: a series of five cases. Open Neurol J. 2013; 7:32-7. 